\title{
Optimizing the Use of Zakat, Infaq, and Alms Funds Based on the Empowerment of Pesantren
}

\author{
Ferry Khusnul Mubarok $^{1}$, Siti Mujibatun ${ }^{2}$, Ali Murtadho ${ }^{3}$, Ahmad Furqon ${ }^{4}$ \\ Faculty of Islamic Economics and Business, Universitas Islam Negeri Walisongo Semarang, \\ Indonesia \\ \{1 ferrykhusnulmubarok@walisongo.ac.id, ${ }^{2}$ sitimujibatun@walisongo.ac.id \\ 3alimurtadho@walisongo.ac.id, ${ }^{4}$ ahmadfurqon@walisongo.ac.id\}
}

\begin{abstract}
The management of zakat, infaq and alms funds has not been optimal, due to the collection and distribution constraints. This article aims to identify the management of zakat, infaq, and alms based on empowerment of pesantren (Islamic Boarding School). The method used is a qualitative approach. Primary data source through interviews, while secondary data through literature search. The data analysis technique used a descriptive approach. The results show that the collection is obtained through zakat fitrah, zakat maal, infaq boxes and alms, and funds from the management's business. Meanwhile, the allocation is through the Santri Mulia Scholarship, Mulia Mandiri Economics, and Insan Sehat Mulia. The allocation focuses on four sectors, such as education, health, socio-religious and economic programs. Fund management constraints include low public awareness, lack of socialization, rejection from muzakki, lack of human resources, and criminal practices. Strategies for improving management through outreach and education to the community.
\end{abstract}

Keywords: Zakat; Infaq; Alms; Islamic Boarding Schools; Empowerment; Utilization

\section{Introduction}

Zakat is a pillar of Islam which has two dimensions [1], namely the world and the hereafter [2]. The dimension of the hereafter is related to obligations to Allah SWT, where the purpose of zakat is to clean one's property and soul [3]. The world dimension is related to human relations (hablumminannas), as a means of helping each other as a instrument of philanthropy [4]-[6]. Zakat in the perspective of social interests is managed in two ways, namely consumptive and productive [7], [8]. Management in productive activities aims to improve the welfare and economic independence of the people [9], [10]. Zakat is one of the characteristics of the Islamic economic system which contains the principle of justice [11], [12], namely the transfer of income from muzakki to mustahik [13], [14]. The hope is that the transfer of income, if managed productively, can turn a mustahik into a muzakki [15], [16]. So far, the utilization of zakat, donations and alms that focuses on poverty alleviation through empowerment [17], [18]. Various patterns of empowerment have been carried out, ranging from providing capital, business assistance, training to improve skills, providing scholarships, 
workshops, seminars and incubation programs, as well as various activities to provide understanding of productive activities. The results of these programs were not a few that were successful, but not a few were failures [19]. The most significant failures have to do with the sustainability of the program. The average failure rate was because the program was only partial and unsustainable. Some of the factors that led to this failure included the lack of human resources both in terms of quantity and quality [20], lack of coordination between institutions [21], competition between institutions in showing their existence [22], lack of awareness of muzakki, institutional problems [23], problem of legality [2], [24], [25], problem of trust [26]-[28], lack of synergy between institutions and government [29]-[31], etc.

Productive activity-based empowerment has been going on, whether successful or not [32]. Another pattern that needs to be further developed is education-based empowerment. Why is that, because one of the factors causing poverty is low education [33], [34]. One of the institutions that started to manage zakat, donations and alms is the pesantren. Pesantren is an educational institution that prioritizes education based on scientific integration, both general and religious sciences [35]. With this pattern, it is hoped that the students will have provisions for life both in terms of the world and the hereafter. From the world side, the students are equipped with entrepreneurial skills for economic independence. Entrepreneurial skills do not refer to specific jobs, but are taught how to create their own jobs. Meanwhile, the aspect of the hereafter is related to the provision of life after death. This article focuses on pesantren-based zakat management. The purpose of this article is to identify collection and utilization management, and identify strategies for optimizing the management of zakat, infaq, and alms funds based on empowerment of pesantren.

\section{Methodology}

This article uses a qualitative method. The data sources used are primary and secondary. Primary data is through interviews with the management and mustahik Amil Zakat, Infaq and Alms Institution (LAZIS) At-Tasyrif Warrohman Semarang, while secondary data is through literature searches, such as books, research results, internet sources, and other relevant sources. Data collection techniques through in-depth interviews and observations. The indepth interview technique emphasizes unstructured interviews. Observation technique through non-participant observation. The data analysis technique used a descriptive analysis approach, using the Miles and Huberman model. This model emphasizes that the researcher analyzes respondents' answers during the interview process. If you have not found an answer to the problem, the researcher can ask questions until they find credible data. Miles and Huberman's analysis model consists of three stages [36]. First, data reduction, namely the process of summarizing, selecting main points, focusing on important data, and eliminating irrelevant data. Second, presenting the data with a brief description and relationships based on categories. Third, drawing conclusions based on various data that has been collected in the field. 


\section{Result dan Discussion}

\subsection{Management of Collection and Distribution of Zakat, Infaq and Alms}

The Amil Zakat, Infaq, and Alms (LAZIS) at-Tasyrif Warrohman Semarang is a philanthropic institution that focuses on developing Islamic boarding schools, under the At Tasyrif Warrohman Foundation. The history of LAZIS At-Tasyrif Warrohman begins with the establishment of the At Tasyrif Warrohman Islamic boarding school. The background of the establishment of this institution is due to the poverty of the community. The main objective of this institution is to alleviate poverty [37], through the empowerment of Islamic boarding schools which are intended for orphans. Empowerment is carried out by providing the education they deserve. One of the reasons for poverty is lack of education. This approach is interdisciplinary, namely by increasing knowledge and skills, with the hope that later they will have the ability to compete and gain equal access to other children. In addition, this institution was established in order to increase public awareness of giving zakat. This institution has several programs, among others, the BASAM Program (Santri Mulia Scholarship), which is a scholarship aimed at students and the less fortunate community. There are several scholarships, namely full and partial scholarships. Full scholarships are intended for children who live and live in Islamic boarding schools, while partial scholarships are for children who do not live. The IMAM program (Ekonomi Mandiri Mulia) is a community empowerment program through productive business activities. Several activities that have been realized include; instant powder herbal medicine, catfish farming, plastic recycling, etc. The ISHAM program (Insan Sehat Mulia) is a health program, both for students and orphans who live in Islamic boarding schools.

The collection of funds is obtained through several sources, such as: (a) Infaq alms boxes entrusted to stalls and shops. The charity boxes totaled 1,000 boxes which were distributed in various regions. The collection of funds through the charity box is carried out once a month, with an average of Rp. 35,000, - per month. (b) Zakat Fitrah during the month of Ramadan and the Eid al-Fitr holidays. (c) Zakat of assets (maal) of the people who have the obligation to pay them. Based on the results of interviews, more zakat maal was obtained from people outside the region, because the local economy was less well off. (d) Fund from the management's business, through a productive fund scheme. Fund distribution is given to mustahiq, which is allocated to several sectors, including: education, social-community, religious and economic sectors. The education sector is carried out through a scholarship program for boarding school children, meeting educational needs such as purchasing uniforms, stationery, and other school needs. The social program includes donations for orphans and underprivileged widows, through the provision of basic necessities. Activities in the religious sector include the purchase of books to help sustain students' learning activities, and the construction of mosques. The economic sector program is channeled through productive activities, which are managed by the board, such as catfish farming, red ginger products, plastic processing, opening boarding houses. The proceeds are used as additional funds to meet the daily needs of students and orphans.

\subsection{Constraints and Management Strategies of Zakat, Infaq and Alms Funds}

The collection and utilization of Zakat, Infaq and Alms funds, the management is constrained by several factors, including (a) Low public awareness, especially channeling through institutions. (b) Lack of community support, indicated by the small amount of funds 
collected, because the local community is less well off. (c) There were rejection from several parties, for example the stall owner refused when leaving the charity box. (d) The existence of a criminal act, such as taking a charity box by a party claiming to be an officer. (e) Lack of human resources as management, both human resources that focus on collection and distribution. The constraints in managing zakat, infaq and alms funds are mainly related to the lack of socialization and education, which causes the public to be less familiar. Thus, the strategic focus focuses on socialization and education. In more detail, the strategy can be done by making stickers and calendars that are given to the community and shop owners. The hope is that the community can get to know more, and can increase their confidence in channeling funds to institutions.

\subsection{Optimizing the Use of Zakat, Infaq, and Alms Funds in Islamic Boarding School- Based Empowerment}

The successful use of zakat, infaq, and alms is determined by the management system, both collection and distribution. The empowerment program has been researched a lot, but each institution has its characteristics, so the handling must be different. Ways to optimize collection by increasing the quantity, such as expanding the collection area and increasing collection instruments. To expand the collection area, it is done by utilizing information technology, for example by utilizing digital applications. On the other hand, distribution optimization focuses on improving the quality of programs to empower mustahik, and improve the quality of human resources in managers. The biggest challenge for the Amil Zakat, Infaq, and Alms Institute refers to sustainable programs, because the programs carried out are short-term. In fact, to create an empowered society, it needs special treatment and takes a long time.

The empowerment program is one of the alternative solutions in alleviating poverty [38]. Basically, when someone pays zakat, infaq and alms is part of investment activity, namely investing in the hereafter. In line with the utilization of LAZIS At-Tasyrif Warrohman Semarang, where the allocation focuses on empowerment programs to alleviate poverty [39]. The focus of empowerment based on pesantren, where children who are unable to be empowered by these institutions, hope that they will have the ability and economic independence. The objective of empowerment to alleviate poverty can be carried out in several sectors, including: education, health, socio-religious, and economy. One of the factors causing poverty is the low level of education. The correlation between poverty and education is quite significant, because education is the initial capital for a person to have abilities, through mastery of knowledge and skills. Efforts to alleviate poverty in the field of education, namely allocating funds to finance schools for students (underprivileged children). Poverty alleviation through education is the best decision, because the root of poverty is related to education [40]. Increasing welfare is also carried out through the provision of basic foodstuffs to orphans and widows around the institution. In the economic sector, zakat, infaq and alms funds are allocated through the provision of venture capital. Provision of venture capital is distributed only to the management, to be managed through the business, where the proceeds will be allocated to the institution. 


\section{Conclusion}

Based on the analysis and discussion shows that fund collection is through zakat fitrah, zakat maal, alms infaq box media, and funds from the management. Meanwhile, the allocation of funds is through the BASAM program (Santri Mulia Scholarship), IMAM (Mandiri Mulia Economics), and ISHAM (Insan Sehat Mulia). The allocation of these funds focuses on four sectors, namely education, health, socio-religion and economy. Management constraints, such as low public awareness, lack of socialization, rejection from muzakki, lack of human resources, and criminal practices. The strategy of improving management focuses on socialization and education to the community (muzzakki).

\section{Suggestion}

Management of pesantren-based zakat, infaq and alms funds needs to work in synergy with various related parties, so that educational operations do not rely solely on these funds. In addition, to improve management, it can be done using the media of information technology, so that education and outreach can be broader.

\section{References}

[1] M. B. O. Yusuf and A. M. Derus, "Measurement model of corporate zakat collection in Malaysia: A test of diffusion of innovation theory," Humanomics, vol. 29, no. 1, pp. 61-74, 2013, doi: 10.1108/08288661311299321.

[2] M. Adachi, "Discourses of Institutionalization of Zakat Management System in Contemporary Indonesia: Effect of the Revitalization of Islamic Economics," Int. J. Zakat, vol. 3, no. 1, pp. 25-35, 2018, doi: 10.37706/ijaz.v3i1.71.

[3] S. Viciawati Machdum, S. Daryanti, J. Debora Imelda, and I. Rukminto Adi, "Crucial Dimensions in Organization Management of Indonesian Islamic Almsgiving (Zakah) Institutions: Insights for Community Economic Empowerment a Review of the Literature," South East Asian J. Manag. •, vol. 9, no. 2, pp. 157-172, 2015.

[4] Tong, "Identifying the poor and the needy among the beneficiaries of zakat: a need for zakat-based poverty threshold in Nigeria," Int. J. Soc. Econ. Int. J. Educ. Manag. Iss Horiz., vol. 44, no. 4, pp. 132-136, 2017, [Online]. Available: http://dx.doi.org/10.1108/03068299110143436\%5Cnhttp://\%5Cnhttp://dx.doi.org/10.1 108/10748121211272452.

[5] S. Javaid and H. A. N. Al-Malkawi, "Corporate social responsibility and financial performance in Saudi Arabia: Evidence from Zakat contribution," Manag. Financ., vol. 44, no. 6, pp. 648-664, 2018, doi: 10.1108/MF-12-2016-0366.

[6] O. H. Rawashdeh, T. Azid, and M. A. Qureshi, "Philanthropy, markets, and Islamic financial institutions: a new paradigm," Humanomics, vol. 33, no. 4, pp. 563-578, 2017, doi: 10.1108/H-08-2016-0063.

[7] P. Wulandari and S. Kassim, "Issues and challenges in financing the poor: case of Baitul Maal Wa Tamwil in Indonesia,” Int. J. Bank Mark., vol. 34, no. 2, pp. 216-234, 2016, doi: 10.1108/IJBM-01-2015-0007.

[8] C. Bilo and A. C. Machado, "The role of Zakat in the provision of social protection: A comparison between Jordan and Sudan," Int. J. Sociol. Soc. Policy, vol. 40, no. 3-4, pp. 236-248, 2020, doi: 10.1108/IJSSP-11-2018-0218.

[9] D. Mustafa, A. J. Baita, and H. D. Adhama, "Quantitative Economic Evaluation of 
Zakah-Poverty Nexus in Kano State, Nigeria," Int. J. Islam. Econ. Financ., vol. 3, no. 1, pp. 21-50, 2020, doi: 10.18196/ijief.2120.

[10] M. Fitri, "Pengelolaan Zakat Produktif sebagai Instrumen Peningkatan Kesejahteraan Umat," Econ. J. Ekon. Islam, vol. 8, no. 1, p. 149, 2017, doi: 10.21580/economica.2017.8.1.1830.

[11] N. A. Zauro, R. A. J. Saad, and N. Sawandi, "Enhancing socio-economic justice and financial inclusion in Nigeria: The role of zakat, Sadaqah and Qardhul Hassan," $J$. Islam. Account. Bus. Res., vol. 11, no. 3, pp. 555-572, 2020, doi: 10.1108/JIABR-112016-0134.

[12] M. Bouanani and B. Belhadj, "Does Zakat reduce poverty? Evidence from Tunisia using the Fuzzy Approach," Metroeconomica, vol. 71, no. 4, pp. 835-850, 2020, doi: 10.1111/meca.12304.

[13] R. S. Rahmat and M. S. Nurzaman, "Assesment of zakat distribution: A case study on zakat community development in Bringinsari village, Sukorejo district, Kendal," Int. J. Islam. Middle East. Financ. Manag., vol. 12, no. 5, pp. 743-766, 2019, doi: 10.1108/IMEFM-12-2018-0412.

[14] K. I. Dandago, A. D. Muhammad, and S. A. Abba, "Behavioral Intention To Pay Zakah on Employment Income Among Academicians in Kano State, Nigeria," Journal of Islamic Monetary Economics and Finance, vol. 2, no. 1. pp. 41-64, 2016, doi: 10.21098/jimf.v2i1.591.

[15] F. K. Mubarok, "Optimalisasi Produk Qardhul Hasan dalam Memberdayakan Ekonomi Umat," Akuntabel, vol. 16, no. 1, pp. 62-68, 2019, doi: 10.29264/jakt.v16i1.4638.

[16] N. Abdullah, A. M. Derus, and H. A. N. Al-Malkawi, "The effectiveness of zakat in alleviating poverty and inequalities a measurement using a newly developed technique," Humanomics, vol. 31, no. 3, pp. 314-329, 2015, doi: 10.1108/H-02-20140016 .

[17] A. R. Abdul-Majeed Alaro and A. H. Alalubosa, "Potential of Sharī'ah compliant microfinance in alleviating poverty in Nigeria: A lesson from Bangladesh," Int. J. Islam. Middle East. Financ. Manag., vol. 12, no. 1, pp. 115-129, 2019, doi: 10.1108/IMEFM-01-2017-0021.

[18] I. Ali and Z. A. Hatta, "Zakat as a poverty reduction mechanism among the muslim community: Case study of Bangladesh, Malaysia, and Indonesia," Asian Soc. Work Policy Rev., vol. 8, no. 1, pp. 59-70, 2014, doi: 10.1111/aswp.12025.

[19] R. Rini, "a Review of the Literature on Zakah Between 2003 and 2019," Int. J. Econ. Financ. Issues, vol. 10, no. 2, pp. 156-164, 2020, doi: 10.32479/ijefi.9035.

[20] A. Hasan, R. Hassan, E. R. A. Engku Ali, E. M. T. Engku Ali, M. Abduh, and N. H. Noordin, "A proposed human resource management model for zakat institutions in Malaysia," ISRA Int. J. Islam. Financ., vol. 11, no. 1, pp. 98-109, 2019, doi: 10.1108/IJIF-10-2017-0036.

[21] N. Abd. Wahab, Z. Zainol, and M. Abu Bakar, "Towards developing service quality index for zakat institutions," J. Islam. Account. Bus. Res., vol. 8, no. 3, pp. 326-333, 2017, doi: 10.1108/JIABR-09-2015-0040.

[22] N. A. Wahab and A. Rahim Abdul Rahman, "A framework to analyse the efficiency and governance of zakat institutions," J. Islam. Account. Bus. Res., vol. 2, no. 1, pp. 43-62, 2011, doi: 10.1108/17590811111129508.

[23] A. Tahiri Jouti, "An integrated approach for building sustainable Islamic social finance ecosystems," ISRA Int. J. Islam. Financ., vol. 11, no. 2, pp. 246-266, 2019, doi: 10.1108/IJIF-10-2018-0118. 
[24] W. bin M. Cokrohadisumarto, Z. Zaenudin, B. Santoso, and S. Sumiati, "A study of Indonesian community's behaviour in paying zakat," J. Islam. Mark., vol. 11, no. 4, pp. 961-976, 2019, doi: 10.1108/JIMA-10-2018-0208.

[25] S. A. Bin-Nashwan, H. Abdul-Jabbar, S. A. Aziz, and A. Haladu, "Zakah compliance behavior among entrepreneurs: economic factors approach," Int. J. Ethics Syst., vol. 36, no. 2, pp. 285-302, 2020, doi: 10.1108/IJOES-09-2019-0145.

[26] M. Y. Owoyemi, "Zakat management: The crisis of confidence in zakat agencies and the legality of giving zakat directly to the poor," J. Islam. Account. Bus. Res., vol. 11, no. 2, pp. 498-510, 2020, doi: 10.1108/JIABR-07-2017-0097.

[27] R. A. Kasri and N. I. S. Putri, "Fundraising Strategies to Optimize Zakah Potential in Indonesia : An Exploratory Qualitative Study," vol. 10, no. January, pp. 1-24, 2018.

[28] M. Ahmad, "An empirical study of the challenges facing zakat and waqf institutions in Northern Nigeria," ISRA Int. J. Islam. Financ., vol. 11, no. 2, pp. 338-356, 2019, doi: 10.1108/IJIF-04-2018-0044.

[29] H. S. Nahar, "Exploring stakeholders' views on a corporatized zakat institution's management performance," Int. J. Ethics Syst., vol. 34, no. 4, pp. 608-631, 2018, doi: 10.1108/IJOES-08-2018-0115.

[30] M. O. A. Mustafa, M. H. S. Mohamad, and M. A. Adnan, "Antecedents of zakat payers' trust in an emerging zakat sector: an exploratory study," Eletronic Libr., vol. 4, no. 1, pp. 4-25, 2013.

[31] R. A. J. Saad and A. U. Farouk, "A comprehensive review of barriers to a functional Zakat system in Nigeria: What needs to be done?," Int. J. Ethics Syst., vol. 35, no. 1, pp. 24-42, 2019, doi: 10.1108/IJOES-06-2018-0090.

[32] D. Masyita, "Lessons Learned of Zakat Management from Different Era and Countries," Al-Iqtishad J. Ilmu Ekon. Syariah, vol. 10, no. 2, pp. 441-456, 2018, doi: 10.15408/aiq.v10i2.7237.

[33] S. Assari, "Parental education better helps white than black families escape poverty: National survey of children's health," Economies, vol. 6, no. 2, pp. 1-14, 2018, doi: 10.3390/economies6020030.

[34] K. Briar-Lawson and S. Austin, Poverty, policy, and ideology. France: UNESCO, 2008.

[35] A. Alhifni, N. Huda, M. Anshori, and B. Ahwarumi, "Product Design Mall of Islamic Microfinance Institutions Supporting Economic Empowerment Islamic Boarding School Indonesia (Case Study Islamic Boarding School Abdussalam)," Int. J. Econ. Financ. Issues, vol. 8, no. 4, pp. 250-255, 2018.

[36] U. Flick, von K. Ernst, and I. Steinke, A Companion to Qualitatif Research. Glasgow: SAGE Publications, 2004.

[37] O. I. Abdussalam, F. Johari, and M. Alias, "Is zakah effective to alleviate poverty in a Muslim society?: A case of Kwara State, Nigeria," Glob. J. Al-Thaqafah, vol. 5, no. 1, pp. 33-41, 2015, doi: 10.7187/GJAT762015.05.01.

[38] A. Senadjki and J. Sulaiman, "An empirical study on the influence of Islamic values in poverty alleviation," J. Islam. Account. Bus. Res., vol. 6, no. 2, pp. 222-243, 2015.

[39] S. A. Shaikh, "Poverty alleviation through financing microenterprises with equity finance," J. Islam. Account. Bus. Res., vol. 8, no. 1, pp. 87-99, 2017, doi: 10.1108/JIABR-07-2013-0022.

[40] M. Selim and M. O. Farooq, "Elimination of poverty by Islamic value based cooperative model," J. Islam. Account. Bus. Res., vol. 11, no. 5, pp. 1121-1143, 2020, doi: 10.1108/JIABR-08-2018-0125. 
